\title{
Factors Forming Firm Performance of Micro-Businesses
}

\author{
Megawati $^{1 *}$, Aimatul Yumna ${ }^{2}$, Charoline Cheisviyanny ${ }^{3}$, Abel Tasman $^{4}$ \\ 1,2,3,4 Universitas Negeri Padang, Padang, Indonesia \\ *Corresponding author. Email: megawati.me@gmail.com
}

\begin{abstract}
Micro-businesses are part of MSMEs and an economic booster, a vibrant and profitable segment in any developing country such as Indonesia. As a business entity, micro-enterprises are expecting to have good company performance to survive. This study aims to analyze the four factors that shape micro-enterprises' performance in the city of Padang. Those factors are financial literacy, financial inclusion, internal locus of control, and risk perception. This research was using a total of 119 samples from all micro-businesses based on clustered proportional random sampling. The data were analyzed using multiple regression analysis. The results showed that financial literacy, financial inclusion, internal locus of control, and risk perception directly affect micro-businesses performance.
\end{abstract}

Keywords: firm performance, firm performance, financial inclusion, locus of control, risk perception.

\section{INTRODUCTION}

Small to medium-sized enterprises in a country have a significant role to play in the economy. MSMEs have the potential to create jobs for the poor [1]. Micro, small and medium enterprises (MSMEs) can bring significant benefits to the economy. UMKM plays a major role in ensuring labor is absorbed. MSMEs possess strong economic stability and sustainability to withstand economic fluctuations.

The economic crisis that occurred in Indonesia in 1998 caused an increase in MSMEs in Indonesia. Furthermore, based on a survey conducted by the Financial Services Authority (OJK), in 2012 the MSME sector has proven to significantly contribute to the national economy by contributing nearly 60 percent of gross domestic product and absorbing a workforce of 97 percent (OJK Press Release: SP38 / DKNS / OJK / $5 / 2016$ ). To ensure the sustainability of their business activities, small and medium-sized enterprises must think about the right way or steps for their business's success.
When it comes to creating business success, it will undoubtedly achieve if the small and medium-sized enterprises can achieve good performance. Performance is a general term used for part or all of a company's actions or activities in a given period. In particular, the version is the definition of specific measures that can measure a business's success in generating profits [2]. A company's performance is a formal effort made by a company to effectively and efficiently evaluate any company activity carried out over a particular time. Financial performance, mainly, in a company is a description of its financial condition, which is analyzed using financial analysis tools to reflect its good or bad state, reflecting the company's performance over a particular time [3]. These results are consistent with [4] results, which shows that the assessment of micro business performance cannot carry out solely based on financial statement data, since the information contained in financial reports has a historical character. It can conclude that it is impossible to predict its financial stability based on its economic indicators accurately. 
Several factors affect the performance of small and medium-sized enterprises. Research conducted by [5] indicates that financial literacy impacts micro business performance and sustainability. He also said that there was a significant challenge for micro businesses creative owners to have more knowledge of financial literacy. [6] argue that financial literacy is a person's ability to manage information about the economy, make financial plans and make better decisions about wealth accumulation, pensioners and the debt they have. This definition reflects the need for a person to gather relevant and essential information, distinguish between different financial options, discuss monetary and economic issues, plan, and determine financial use decisions. Financial literacy is related to the habits, behavior and influence of external factors.

Financial inclusion is included in the financial literacy program, significantly to increase the ability of micro business owners to use financial services and directly impact financial institutions [7]. The higher the increase in financial inclusion of micro businesses, it will ultimately increase financial stability. Financial inclusion is a change in the mindset of economic agents on how to view profit and money. Financial inclusion can interpret as the ease of obtaining financial services in economic activities. Financial inclusion is also essential because optimizing funding sources helps micro businesses to be more productive and develop. Financial management has a role in determining the extent to which the performance of micro businesses. Research conducted by [3] shows that financial inclusion has a significant effect on micro businesses performance. The study states that financial literacy has not been achieved on a large scale if there are still problems with asymmetrical information on financial services so that it can hinder the success of micro businesses to compete. With better financial literacy and financial inclusion, business actors can use their financial skills in making various decisions. Small and medium-sized enterprises with better financial literacy will implement strategic plans to identify opportunities and threats. It should also have adequate financial access and respond to changes in the unstable business climate so that decisions taken can provide innovative and targeted solutions to improve small and medium-sized enterprises' performance.

[8] study revealed that only respondents from the banking sector have high financial literacy than other industries. MSMEs, which are one of the economy's backbones, must receive high financial literacy better financial inclusion. Research conducted by [5] shows a significant influence between financial inclusion and micro businesses. Financial inclusion itself also influences the performance of micro businesses. Research conducted by [9] states that financial inclusion has a positive effect on MSMEs' growth, in particular for micro businesses. The study conducted by [8] also notes a significant relationship between financial inclusion and micro businesses development. They also said that the financial inclusion policy had a positive and significant impact on MSME operations. Therefore, financial inclusion is needed to increase financial literacy. Financial inclusion is all kinds of ways to make it easier for people to get financial services. Financial inclusion aims to remove all forms of barriers to public access in utilizing financial services supported by existing infrastructure.

The next factor is a locus of control. Locus of control is useful when it comes to your finances, and lack thereof will affect it in negative ways. Therefore, a micro businesses owner, especially in the city of Padang, needs to be proficient in financial planning, making good decisions, and efficient business management in order to maximize profits. The study conducted by [10] stated that the locus of control has a positive effect on the performance of micro businesses.

Risk perception, also known as risk attitude, is a rational or irrational belief held by individuals, groups, and society about the possibility of the risk occurring [11]. Risk perception is critical for small and mediumsized enterprises, especially in developing countries [12]. According to [13], a company's earnings are positively influenced by the perception of risks, which indicates its performance. Based on the background regarding the low level of financial literacy of micro businesses owners need to control behaviour and be aware of risks for improvement of performance.

\section{RESEARCH METHODS}

The population of this research is all Micro, Small, and Medium Enterprises (UMKM) actors in the city of Padang. Based on data obtained from the Padang City Cooperatives and UMKM Office in 2017, the number of Micro, Small, and Medium Enterprises in Padang City is 
89,699. Details of the number of MSMEs can be seen in Table 1.

Table 1: Samples Selection

\begin{tabular}{|l|c|c|c|}
\hline $\begin{array}{c}\text { Type of } \\
\text { Business }\end{array}$ & $\begin{array}{c}\text { SMEs } \\
\text { Population }\end{array}$ & $\begin{array}{c}\text { Clustered } \\
\text { Sampling }\end{array}$ & Samples \\
\hline Micro & $\mathbf{2 6 . 6 9 9}$ & $\mathbf{( 2 6 . 6 9 9 / 8 9 . 6 9 9 ) * 3 9 9}$ & $\mathbf{1 9 9}$ \\
Small & 50.127 & $(50.127 / 89.699) * 399$ & 223 \\
Medium & 12.873 & $(12.873 / 89.699) * 399$ & 57 \\
\hline Jumlah & 89.699 & & 399 \\
\hline
\end{tabular}

Using the Slovin formula, 399 Micro, Small, and Medium Enterprises (MSMEs) in Padang City were determined to be used as the selected sample. After the number of samples is known, the clustered proportional sampling method is used to determine the sample size for each business classification. According to [14], clustered proportional random sampling selects samples based on groups. Thus it is determined that the sample used in this study is only micro-enterprises, namely as many as 119 micro businesses. Model testing uses multiple regression analysis techniques. The following is the design of this study:

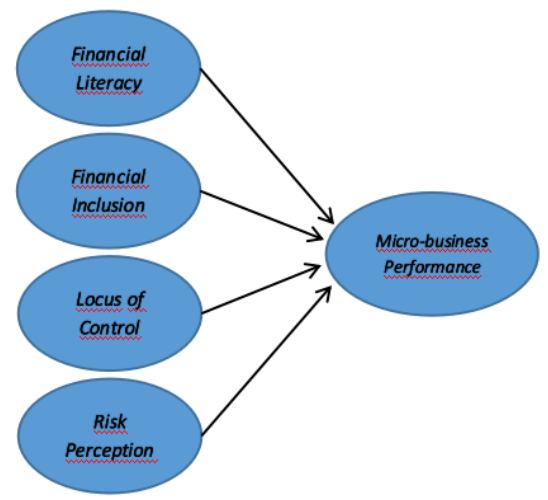

Figure 1. Conceptual Framework

\section{RESULT AND DISCUSSION}

The classical assumption test results show that the model for the formation of micro-business performance in the city of Padang has met the requirements of the classical assumption test, which includes the normality test, heteroscedastic, and multicollinearity test. The results of multiple regression analysis can be seen in Table 2 below.

From the test results above, it can be concluded that financial literacy, internal locus of control, and financial inclusion positively and significantly affect company performance. Meanwhile, on the other hand, risk perception has a negative and significant effect on company performance. Financial literacy has a positive effect on the performance of micro-businesses in the city of Padang. It means that the better the financial literacy owned by the micro-business owner, the better his understanding of creating a firm performance. Thus, the first hypothesis in this study can be accepted.

Table 2 Results of Multiple Regression Test

\begin{tabular}{|l|r|r|r|r|r|}
\hline \multirow{2}{*}{ Model } & \multicolumn{2}{|c|}{$\begin{array}{c}\text { Unstandardized } \\
\text { Coefficients }\end{array}$} & $\begin{array}{l}\text { Standardize } \\
\text { d } \\
\text { Coefficients }\end{array}$ & \multirow{2}{*}{ Sig. } & \\
\cline { 2 - 5 } & \multicolumn{1}{|c|}{ B } & $\begin{array}{c}\text { Std } \\
\text { Error }\end{array}$ & Beta & & \\
\hline (Constant) & -1.947 & 1.771 & & -1.100 & .274 \\
\hline Fin. Literacy & 1.033 & .051 & .846 & 20.249 & .000 \\
\hline Fin. Inclusion & .657 & .657 & .403 & 6.386 & .000 \\
\hline Intern..locus of control & .518 & .158 & .269 & 3.287 & .001 \\
\hline Risk Perception & .580 & .159 & .478 & -3.657 & .000 \\
\hline
\end{tabular}

Microbusiness owners who have good financial literacy will start managing and utilizing financial information to make financial planning and decisions. Thus, a person will be better at determining debt decisions, accumulating wealth, and preparing for retirement. Microbusiness owners will undoubtedly apply this in managing micro businesses. Microbusiness management using the principles of financial literacy will make it easier for micro businesses to achieve good performance. Thus, the survival of this micro business will be longer. This study's results are in line with [15], who also tested the effect of financial literacy on SME's growth, which stated that financial literacy positively impacted micro-businesses' performance.

Next, financial inclusion had a positive effect on the performance of micro-businesses. Its means that the better the financial inclusion of micro-businesses, the better the understanding of micro-businesses on how they can get better financial resources from financial institutions. Thus, the second hypothesis in this study can be accepted. Financial inclusion is a form of linkage between individuals, institutions, or organizations with financial institutions, products, and services to meet the need to improve welfare. Microbusiness owners who have been in frequent contact with formal financial institutions, of course, will be more familiar with the financial products and services offered by these finances. Products and services of legal, financial institutions include savings and credit. Open access to credit as an alternative capital for micro-businesses will undoubtedly open up micro-businesses opportunities to get additional money to meet their capital needs or 
increase their business capacity. Later, of course, it will impact the achievement of better micro-business performance. The results of this study are in line with research conducted by [8] and [16] which states that the financial inclusion variable has a significant effect on the performance of MSMEs. This study indicates that with easy financial services, the performance of MSMEs in a country will increase because of the convenience obtained from financial institutions.

As the internal locus of control had a positive effect on micro-businesses' performance, the better the internal locus of control owned by the Microbusiness owner, the better the micro-business performance. Thus, the third hypothesis in this study can be accepted. Internal locus of control itself is the belief that a person controls the events and consequences that affect a person's life. Internal locus of control can also be said to how a person believes that they maintain their destiny. It shows that their failures and successes are the results of their influence. Therefore, a person or business actor is required to have the ability to plan finances in their business correctly and make decisions effectively and efficiently so that their business can generate maximum profits. This study's results are reinforced by [2], [17] and [18] which states that locus of control is proven to have a significant positive effect on micro businesses performance because it is one of the factors that drive decision-making. The results of his study said that the locus of control had a significant effect on micro businesses performance.

Lastly, the study results stated that risk perception has a negative impact on the performance of micro-businesses in the city of Padang. It means that the higher the micro-business owner's perception of risk, the lower its financial performance. Thus, the fourth hypothesis in this study is rejected. Risk perception is a rational or irrational belief held by individuals, groups, and society about the possibility of the risk occurring in the form of its breadth, magnitude, and impact [11]. Risk perception shows how an investor views a particular risk to make investment decisions that can maximize investor utilization [19]. The study results stated that risk perception has a negative influence on the performance of microbusinesses, which means that the higher the perception of micro business owners on risk, the greater the chance of loss because the risk is identical to uncertainty. It, of course, will has a negative impact on the financial performance of micro- businesses. This study's results are not in line with [13], who state that risk perception has a positive effect on earnings, which is identified as a reflection of company performance.

\section{CONCLUSION}

As a business entity, micro-businesses play an essential role in supporting the nation's economy. For a microbusiness to continue to grow, it is necessary to research the factors that shape its financial performance. The study results concluded that the elements forming the financial performance of micro-businesses in Padang's city were financial literacy, financial inclusion, and internal locus of control. Each of these factors has an impact on micro-businesses firm performance positively and negatively.

\section{REFERENCES}

[1] D. Audtresch, R. Van der Horst, T. Kwaak, and

R. Thuric, “Annual Report on EU Small and

Medium Size Enterprises,” EIM, January, 2009.

[2] R. N. Kusumadewi, "Pengaruh Locus Of

Control dan Financial Literacy Terhadap Kinerja

UKM Pada Pelaku UKM Desa Rawa Kecamatan

Cingambul Kabupaten Majalengka," Prosding

Semin. Nas. dan Call Pap., 2017.

[3] G. Okello Candiya Bongomin, J. M. Ntayi, J. C. Munene, and I. Nkote Nabeta, "Social capital: mediator of financial literacy and financial inclusion in rural Uganda," Rev. Int. Bus.

Strateg., 2016.

[4] I. Kotane and I. Kuzmina-Merlino, "Analysis of Small and Medium Sized Enterprises' Business

Performance Evaluation Practice at

Transportation and Storage Services Sector in Latvia," in Procedia Engineering, 2017.

[5] D. Aribawa, "Pengaruh literasi keuangan terhadap kinerja dan keberlangsungan UMKM di Jawa Tengah,” J. Siasat Bisnis, 2016.

[6] A. Lusardi and O. S. Mitchell, "The economic 
importance of financial literacy: Theory and evidence," J. Econ. Lit., 2014. P. A. Sanistasya, K. Raharjo, and M. Iqbal, "The Effect of Financial Literacy and Financial Inclusion on Small Enterprises Performance in East Kalimantan,” J. Econ., 2019.

[8] P. Quartey, E. Turkson, J. Y. Abor, and A. M. Iddrisu, "Financing the growth of SMEs in Africa: What are the contraints to SME financing within ECOWAS?," Review of Development Finance. 2017.

[9] L. Chauvet and L. Jacolin, "Financial Inclusion, Bank Concentration, and Firm Performance," World Dev., 2017.

[10] D. Apriyani and T. Setiawan, "PENGARUH TIME BUDGET PRESSURE TERHADAP DYSFUNCTIONAL AUDIT BEHAVIOR DENGAN DIMODERASI LOCUS OF CONTROL,” J. Akuntansi, Audit. dan Keuang. Balanc., 2017.

[11] K. Sindhu and R. Kumar, "Influence of Risk Perception of Investors on Investment Decisions: An Empirical Analysis," Int. J. Res. Econ. Soc. Sci., 2014.

[12] A. Rauch, M. Frese, and S. Sonnentag, "Cultural differences in planning/success relationships: A comparison of small enterprises in Ireland, West Germany, and East Germany,” J. Small Bus. Manag., 2000.

[13] D. Willebrands, J. Lammers, and J. Hartog, “A successful businessman is not a gambler. Risk attitude and business performance among small enterprises in Nigeria,” J. Econ. Psychol., 2012.

[14] N. Indriartoro and B. Supomo, "Metodologi Penelitian Untuk Akuntansi Dan Manajemen (Edisi 1)," BPFE. 2016.

[15] C. E. Eresia-Eke and C. Raath, "SMME Owners' financial literacy and business growth," Mediterr. J. Soc. Sci., 2013.
[16] B. Ina Ibor, A. I. Offiong, and E. S. Mendie, "FINANCIAL INCLUSION AND PERFORMANCE OF MICRO, SMALL AND MEDIUM SCALE ENTERPRISES IN NIGERIA," Int. J. Res. -GRANTHAALAYAH, 2017.

[17] R. Purnomo and S. Lestari, "Pengaruh Kepribadian, Self-Efficacy, Dan Locus of Control Terhadap Persepsi Kinerja Usaha Skala Kecil Dan Menengah," J. Bisnis dan Ekon., 2010.

[18] U. Sumantri and D. Gemina, "Pengaruh Faktor Kepribadian Individual, Self-Efficacy Serta Locus of Control Terhadap Kinerja Usaha Mikro Kecil Dan Menengah Di Kecamatan Caringin Kabupaten Bogor,” J. Visionida, 2015.

[19] E. 2010 Tandelilin, "Dasar-dasar Manajemen Investasi," Keuangan, 2010. 